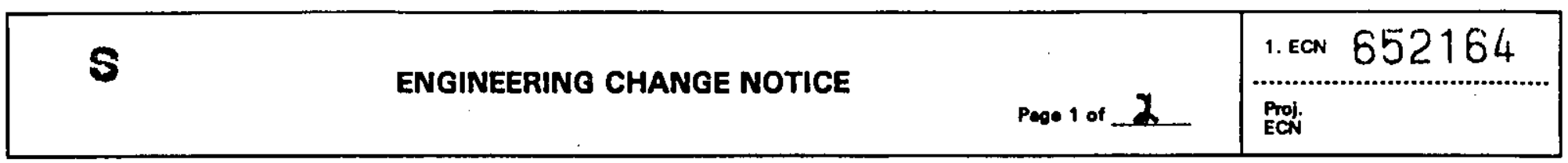

\begin{tabular}{|c|c|c|c|c|c|c|}
\hline \multirow{3}{*}{$\begin{array}{ll}\text { Supplemental } & \square \\
\text { Direct Revision } & \square \\
\text { Change ECN } & \square \\
\text { Temporary } & \square \\
\text { Standby } & \square \\
\text { Supersedure } & \square \\
\text { CancelNoid } & \square\end{array}$} & \multicolumn{3}{|c|}{$\begin{array}{l}\text { Jon Tanke, Proj Planning \& Integration, } \\
\text { R3-56, 376-1718 }\end{array}$} & \multicolumn{2}{|c|}{$\square$ Yes $\square$ No } & $\begin{array}{l}\text { 5. Date } \\
2-10-00\end{array}$ \\
\hline & \multicolumn{2}{|c|}{$\begin{array}{l}\text { 6. Project Title/No. Work Order No.' } \\
\text { Thermal stabilization }\end{array}$} & \multicolumn{3}{|c|}{$\begin{array}{l}\text { 7. Bldg./Sys./Fac. No. } \\
234-5 z\end{array}$} & 8. Approval Designator \\
\hline & \multicolumn{2}{|c|}{$\begin{array}{l}\text { 9. Document Numbers Changed by this ECN (includes } \\
\text { sheet no. and rev.) }\end{array}$} & \multicolumn{3}{|c|}{ 10. Related ECN No(s). } & $\begin{array}{l}\text { 11. Related PO No. } \\
\text { N/A }\end{array}$ \\
\hline $\begin{array}{l}\text { 12a. Modification Work } \\
\square \text { Yes (fil out Blk. 12b) } \\
\square \text { No (NA Blks. 12b, } \\
\text { 12c, 12d) }\end{array}$ & $\begin{array}{l}\text { 12b. Work Package No. } \\
\text { N/A }\end{array}$ & \multicolumn{3}{|c|}{$\begin{array}{l}\text { 12c. Modification Work Completed } \\
\qquad N / A\end{array}$} & \multicolumn{2}{|c|}{$\begin{array}{l}\text { 12d. Restored to Original Condition (Temp. } \\
\text { or Standby ECNs only) }\end{array}$} \\
\hline
\end{tabular}

13a. Description of Change

13b. Design Baseline Document? $\square$ Yes $\square$ No

Complete revision per the attached

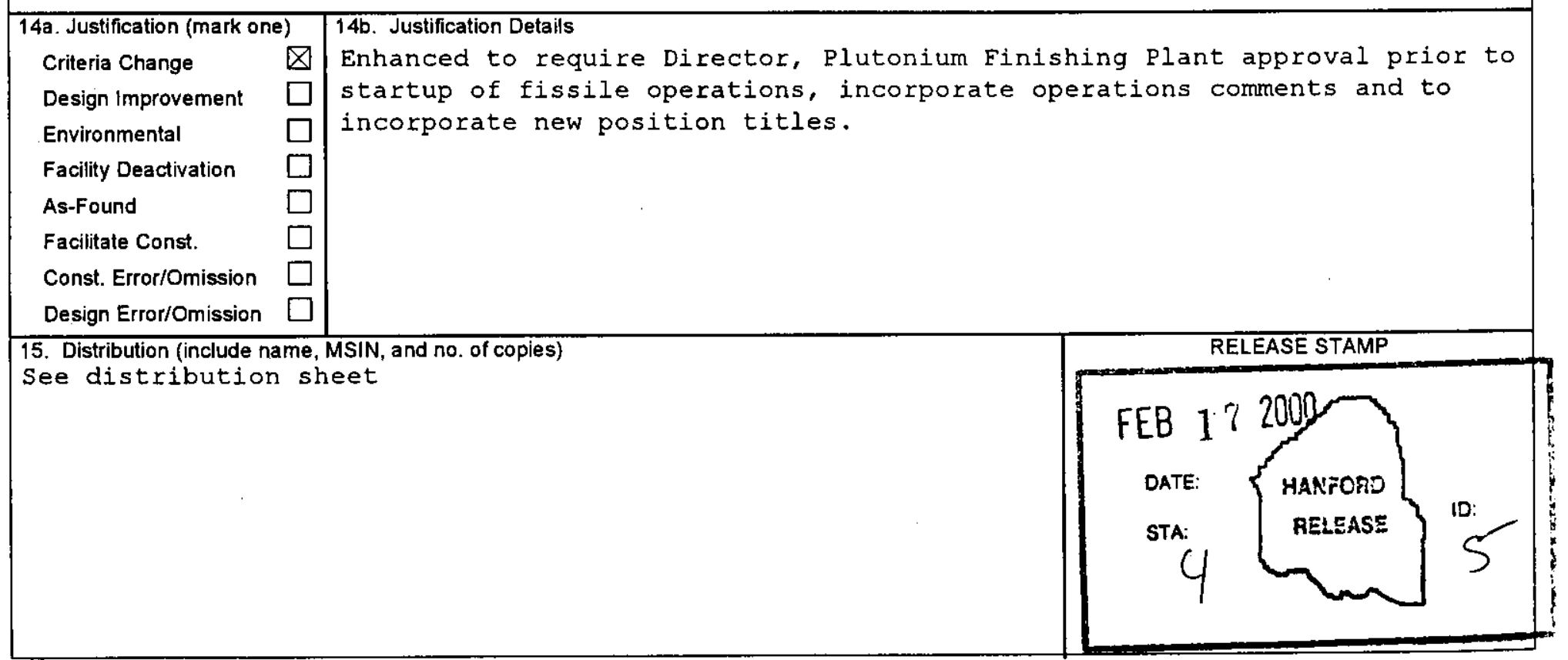




\section{ENGINEERING CHANGE NOTICE}

16. Design Verification Required

$\square$ Yes

$\triangle$ No
17. Cost Impact

ENGINEERING

Additional $\square \leqslant \mathrm{N} / \mathrm{A}$

Savings

$\$ N / A$

\section{CONSTRUCTION}

Additional $\square \$ N$

Savings
Page 2 of $\_2$

18. Schedule Impact (days)

Improvement $\square$ N/A

Delay $\square$ N/A

19. Change Impact Review: Indicate the related documents (other than the engineering documents identified on Side 1) that will be affected by the change described in Block 13. Enter the affected document number in Block 20.

SDD/DD

Functional Design Criteria

Operating Specification

Criticality Specification

Conceptual Design Report

Equipment Spec.

Const. Spec.

Procurement Spec.

Vendor Information

OM Manual

FSAR/SAR

Safety Equipment List

Radiation Work Permit

Environmental Impact Statement

Environmental Report

Environmental Permit

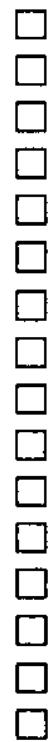

Seismic/Stress Analysis
Stress/Design Report
Interface Control Drawing
Calibration Procedure
Installation Procedure
Maintenance Procedure
Engineering Procedure
Operating Instruction
Operating Procedure
Operational Safety Requirement
IEFD Drawing
Cell Arrangement Drawing
Essential Material Specification
Fac. Proc. Samp. Schedule
Inspection Plan
Inventory Adjustment Request

Tank Calibration Manual

Health Physics Procedure

Spares Multiple Unit Listing

Test Procedures/Specification

Component Index

ASME Coded Item

Human Factor Consideration

Computer Software

Electric Circuit Schedule

ICRS Procedure

Process Control Manual/Plan

Process Flow Chart

Purchase Requisition

Tickler File

None

20. Other Affected Documents: (NOTE: Documents listed below will not be revised by this ECN.) Signatures below indicate that the signing organization has been notified of other affected documents listed below.

Design Authority

Cog. Eng. H.R. Risenmav H Rer Resur Cog. Mgr. M.D. Talbot Mrdachet QA

Safety

Environ.

Other

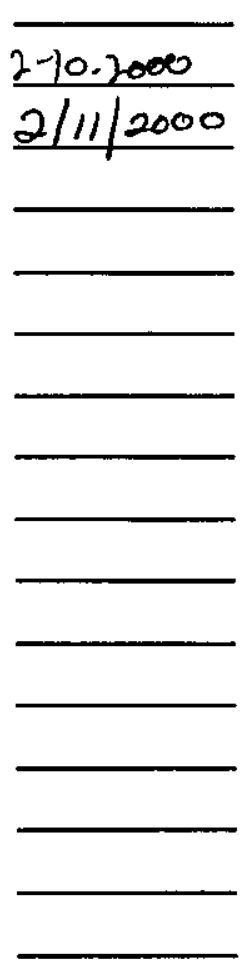

Design Agent

PE

QA

Safety

Design

Environ.

Other

\section{DEPARTMENT OF ENERGY}

Signature or a Control Number that tracks the Approval Signature

ADDITIONAL 


\section{DISTRIBUTION SHEET}

To

Distribution

Project TitleM Work Order

Glovebox HA-21I Furnace Operations Initiation Plan
From

HT Willis

\begin{tabular}{|c|c|c|c|c|c|}
\hline & & \multicolumn{4}{|c|}{ ECN No. 652164} \\
\hline Name & MSIN & $\begin{array}{c}\text { Text } \\
\text { With All } \\
\text { Attach. }\end{array}$ & Text Only & $\begin{array}{c}\text { Attach.I } \\
\text { Appendix } \\
\text { Only }\end{array}$ & $\begin{array}{c}\text { EDT/ECN } \\
\text { Only }\end{array}$ \\
\hline Bond, RA & T5-50 & $x$ & & & \\
\hline Burk, RA & $\mathrm{T} 4-20$ & $x$ & & & \\
\hline Carey, JR & T5-48 & $x$ & & & \\
\hline Curtman, EW & T5-08 & $x$ & & . & \\
\hline Gray, BJ & $\mathrm{T} 5-02$ & $x$ & & & \\
\hline Harder, DD & T5-09 & $x$ & & & \\
\hline Heineman, $\mathrm{RE}$ & T5-50 & $\mathrm{x}$ & & & \\
\hline Jackson, GW & T5-50 & $x$ & & & \\
\hline Jansons, RS & T5-57 & $x$ & & & \\
\hline Lane, ML & T5-01 & $x$ & & & \\
\hline McQuinn, RL & $\mathrm{T} 5-50$ & $\mathrm{x}$ & & & \\
\hline Merkling, TD & T5-57 & $x$ & & & \\
\hline Ramirez, $\mathrm{R}$ & T5-09 & $\mathrm{x}$ & & & \\
\hline Redekopp, RD & T5-15 & $x$ & & & \\
\hline Risenmay, HR & T5-55 & $x$ & & & \\
\hline Roege, $\mathrm{PE}$ & T5-57 & $x$ & & & \\
\hline Romine, DL & T5-09 & $x$ & & & \\
\hline Sax, SM & T5-15 & $\mathrm{x}$ & & & \\
\hline Skeels, BD & T5-09 & $x$ & & & \\
\hline Speer, DR & R3-56 & $\mathrm{x}$ & & & \\
\hline Talbot, MD & H3-26 & $\mathrm{x}$ & & & \\
\hline Willis, HT & T4-19 & $\mathrm{x}$ & & & \\
\hline & & & & & \\
\hline & & & & & \\
\hline & & & & & \\
\hline & & & & & \\
\hline & & & & & \\
\hline & & & & & \\
\hline & & & & & \\
\hline & & & & & \\
\hline & & & & & \\
\hline
\end{tabular}




\title{
Plan for the Startup of HA-21I Furnace Operations at the Plutonium Finishing Plant
}

\author{
HT Willis \\ Fluor Hanford, Inc. \\ Richland, WA 99352 \\ U.S. Department of Energy Contract DE-AC06-96RL13200 \\ EDT/ECN: $E C N-652164$ UC: \\ Org Code: $15100 \quad$ Charge Code: 110847 \\ B\&R Code: \\ Total Pages: 16
}

Key Words:

Muffle Furnace, Thermal Stabilization, PFP, Plutonium, HA-21I

\begin{abstract}
:
This plan provides a phased approach authorizing the use of three additional muffle furnaces for thermal stabilization.
\end{abstract}

TRADEMARK DISCLAIMER. Reference herein to any specific commercial product, process, or service by trade name, trademark, manufacturer, or otherwise, does not necessarly constitute or imply its endorsement, recommendation, or favoring by the United States Government or any agency thereof or its contractors or subcontractors.

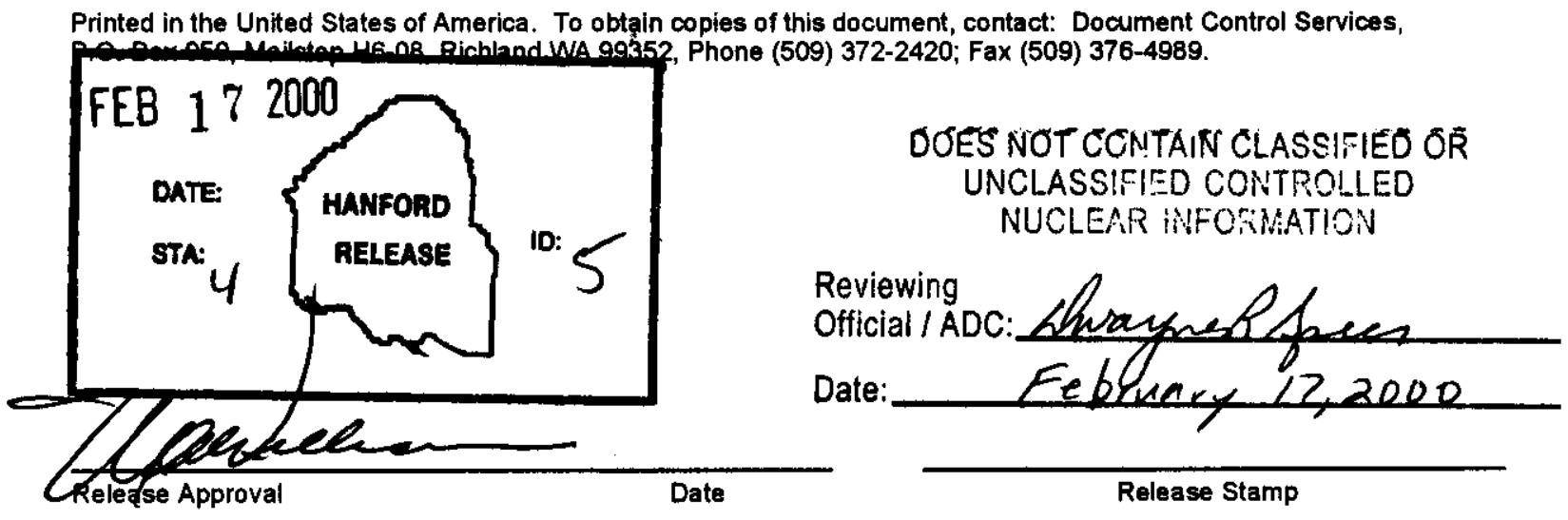




\section{RECORD OF REVISION}

Page 1

(2) Title

Plan for the startup of HA-21I Furnace Operations at the PFP

Change Control Record

(3) Revision

\begin{tabular}{l|l}
1 & Revision per ECN-652164
\end{tabular} (7)
(4) Description of Change - Replace, Add, and Delete Pages

Original issue per EDT 628633

\section{R3.}

Authorized for Release

\begin{tabular}{l|ll}
\hline (5) Cog. Engr. & (6) Cog. Mgr. Date
\end{tabular}

\begin{tabular}{l|l}
\hline & \\
\hline
\end{tabular}




\title{
GLOVEBOX HA-21I FURNACE OPERATIONS STARTUP PLAN
}

\author{
February 2000
}

\section{Revision 1}

APPROVALS:
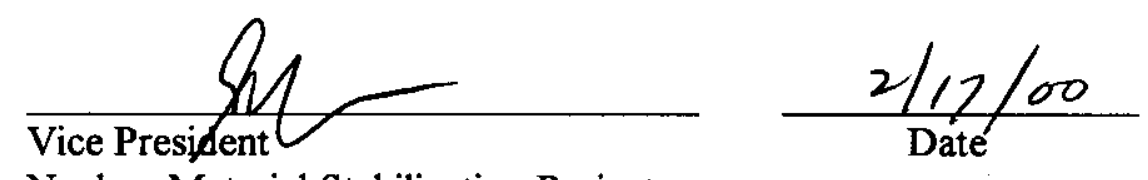

Nuclear Material Stabilization Project

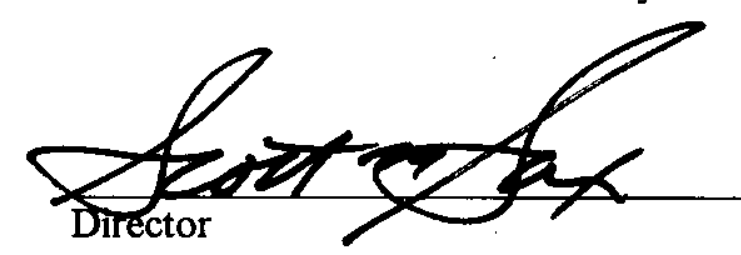

Plutonium Finishing Plant

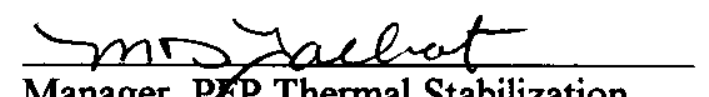
Manager, PFP Thermal Stabilization

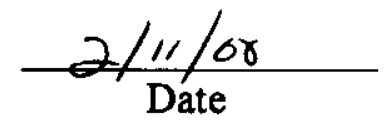

Plutonium Finishing Plant 


\section{TABLE OF CONTENTS}

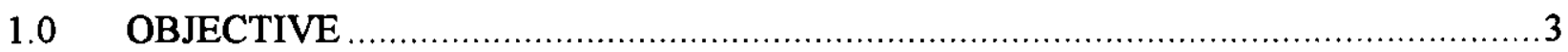

2.0 SCOPE OF THE STARTUP OF HA-21I FURNACES PROCESS $\ldots \ldots \ldots \ldots \ldots \ldots \ldots \ldots \ldots 4$

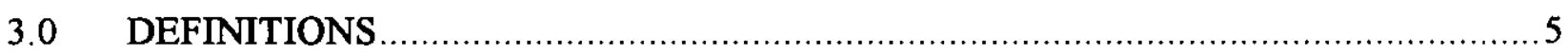

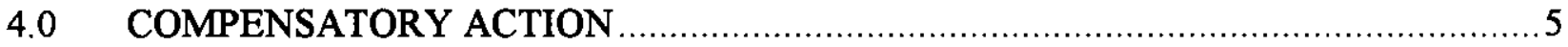

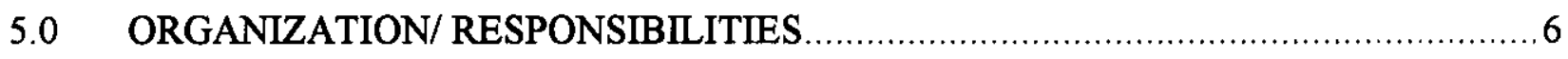

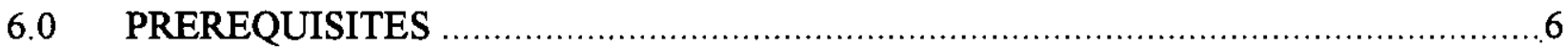

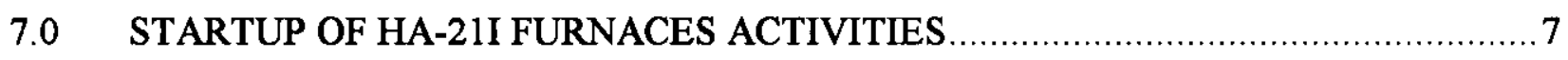

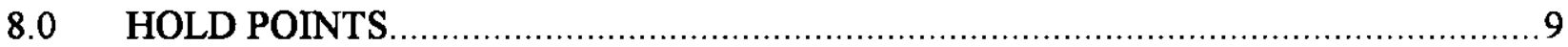

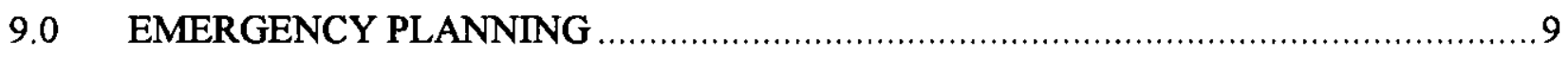

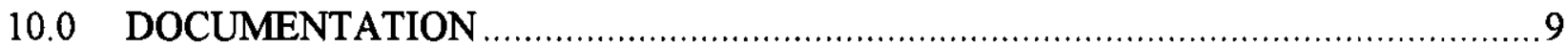

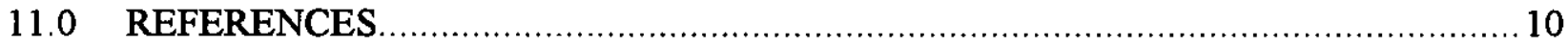

\section{LIST OF FIGURES}

FIGURE 1 Layout of HA-21I Furnaces ............................................................. 11 


\subsection{OBJECTIVE}

Achievement of Thermal Stabilization mission elements require the installation and startup of three additional muffle furnaces for the thermal stabilization of plutonium and plutonium bearing materials at the Plutonium Finishing Plant (PFP). The release to operate these additional furnaces will require an Activity Based Startup Review. The conduct of the Activity Based Startup Review (ABSR) was approved by Fluor Daniel Hanford on October 15, 1999. This plan has been developed with the objective of identifying those activities needed to guide the controlled startup of five furnaces from authorization to unrestricted operations by adding the HA-21I furnaces in an orderly and safe manner after the approval to Startup has been given.

The Startup Plan provides a phased approach that bridges the activities between the completion of the Activity Based Startup Review authorizing the use of the three additional furnaces and the unrestricted operation of the five thermal stabilization muffle furnaces. The four phases are: I the initiation of five furnace operations using three empty (simulated full) boat charges from HA$21 \mathrm{I}$ and two full charges from $\mathrm{HC}-21 \mathrm{C}$; II - three furnace operations (one full charge from HA$21 \mathrm{I}$ and two full charges from HC-21C); III - four furnace operations (two full charges from HA21I and two full charges from HC-21C); and IV - integrated five furnace operations and unrestricted operations. Phase I of the Plan will be considered as the cold runs. This Plan also provides management oversight and administrative controls that are to be implemented until unrestricted operations are authorized. It also provides a formal review process for ensuring that all preparations needed for full five furnace operations are completed and formally reviewed prior to proceeding to the increased activity levels associated with five furnace operations.

Specific objectives include:

1.1. To ensure that activities are conducted in a safe manner.

1.2 To provide supplemental technical and managerial support to Thermal Stabilization activities during the initial use of the HA-21I Furnaces until the commencement of full five furnace, unrestricted operations.

1.3 Ensure that operations can be conducted in a manner that meets PFP and DOE expectations associated with the principles of integrated safety management.

1.4 To ensure that all interfacing activities needed to meet Thermal Stabilization mission objectives are completed. 


\subsection{SCOPE OF THE STARTUP OF HA-21I FURNACES PROCESS}

The scope of the effort for the HA-21I Furnaces shall include the following activities:

- Thermal stabilization of fissile material Building 234-5Z, Rooms 230A and 235B using furnaces in gloveboxes $\mathrm{HC}-21 \mathrm{C}$, and HA-21I.

- Activation of material conveyors in Rooms 230-B, 230-C and 235-B

- Routine handling of fissile Material in support of furnace activities
Building 234-5Z, Rooms 230B, 230C, and 235B

234-5Z Building

See Figure 1 for a layout of the HA-21I Furnaces equipment included in the Activity Based Startup Review. This equipment includes the three new furnaces and support equipment located in glovebox HA-21I, conveyors HA-28, HC-3, HC-4, the new vacuum pumps, and the HC-2/3 airlock.

This Plan has been developed to meet the objectives in Section 1.0. Phase one of this plan may proceed prior to the Activity Based Startup Review. Fissile material operations will be initiated after the completion of the Activity Based Startup Review, and approval has been received. Furnace operations will be commenced in accordance with this plan on the three furnaces in HA-21I. While continuing to operate the existing two furnaces, furnace operations are to be conducted on each HA-21I furnace at the discretion of the Manager, PFP Thermal Stabilization. These runs will operate each of the three furnaces sequentially. To ensure that each incremental level of increasing complexity is properly sequenced, initially, the five furnace production level will be conducted utilizing empty boats in the new furnaces. The second phase will add one full charge in HA-21I and the third phase will include two full charges in HA-21I. The fourth phase will include three full charges in HA-21I. The primary purpose for these sequential furnace runs is to verify operations staff can safely and efficiently coordinate multiple tasks associated with integrated five furnace operations. Hold Points are placed at the beginning of each phase to assure that written approval has been received prior to moving into the next phase.

After initial HA-21I furnace operations are complete, integrated furnace operations will be initiated as appropriate to support production levels, staffing, analytical capabilities, etc. 


\subsection{DEFINITIONS}

3.1 Blend Plan - The plan that identifies the specific material to be processed, and the methodology to be followed for the process.

3.2 Compensatory Actions - Those temporary provisions that have been implemented in addition to normal practices for the purpose of ensuring safe operations until additional operating experience is achieved.

3.3 Manager, PFP Thermal Stabilization - The manager, appointed by the Director, Plutonium Finishing Plant, as having the single point of responsibility for the operation and maintenance of thermal stabilization operations.

3.4 Startup Plan Checklist - A checklist of items to be verified prior to commencing integrated five furnace operations. This checklist (Attachment A) ensures that the actions required to transition from one part of the Startup Plan process to another are done in an orderly fashion. This is accomplished by establishing hold points and review activities at various points of the process.

3.5 Startup Plan for the HA-21I Furnaces (Startup Plan) - The plan describes how Stabilization will transition the HA-21I Furnaces from the completion of the Activity Based Startup Review through full unrestricted operations.

3.6 Vice President, Nuclear Material Stabilization Project - The overall senior manager responsible for the operation of the Plutonium Finishing Plant.

3.7 Senior Supervisory Watch (SSW) - Senior members of PFP Management, selected and trained to provide senior level oversight of various PFP operations.

\subsection{COMPENSATORY ACTIONS}

4.1 The compensatory actions associated with the initiation of the HA-21I furnaces are listed below.

4.1.1 Additional oversight by the Senior Supervisory Watch and other Operations management personnel during the various phases of the operations, as directed by memorandum issued by the Director, Plutonium Finishing Plant. Selected PFP managers who stand SSW watch will provide coaching and mentoring during startup activities with a focus on procedure adherence and good conduct of operations. 
4.1.2 Utilization of empty boats to simulate the additional furnaces being integrated into the operation.

\subsubsection{Utilization of the Startup Plan checklist and Hold Points}

4.2 These compensatory measures are judged to be adequate because of the following:

4.2.1 Operation of Thermal Stabilization processes has been an ongoing evolution since January 15,1999 . The risks and procedures associated with these activities are well known.

4.2.2 The Initiation of the HA-21I furnaces will utilize experienced process operators and supervisors.

4.2.3 Additional personnel needed for five furnace operations will be trained and certified utilizing existing training procedures with an approved training plan.

\subsection{ORGANIZATION/ RESPONSIBILITIES}

5.1 The functional organization for the use of the HA-21I Furnaces will be centered around the Thermal Stabilization Team. This team contains all of the operators, managers, and support personnel to operate and maintain Thermal Stabilization activities. The Analytical Laboratories will provide additional support for sample analysis, and the Vault Team for retrieval and storage of fissile materials.

5.2 The Manager, PFP Thermal Stabilization shall be responsible to the Director, Plutonium Finishing Plant, for the execution of all activities in the Startup Plan. This will include, but not be limited to the review of the Startup Plan activities and approval of each new operational level, with the two exceptions being the Hold Point authorizing fissile material operations and the final Hold Point, and coordination with the Analytical Laboratory and the Technical Support Team.

\subsection{PREREQUISITES}

6.1 Prior to executing fissile material operations under the Startup Plan, approval for the use of the HA-21I Furnaces has been formally provided by the Director, Plutonium Finishing Plant. 


\subsection{INITIATION OF HA-21I FURNACES ACTIVITIES}

\subsection{Fissile Material Operation}

Process operations will be initiated using a graded approach. This approach will be initiated at the beginning of operations without fissile material and continued through the increasingly complex operations with fissile materials in accordance with this Startup Plan.

\subsection{Furnace Operations}

7.2.1.1 Once authorization to commence operations has been given, the new furnaces will be added to the process in a deliberate manner. Operations of the existing $\mathrm{HC}-21 \mathrm{C}$ furnaces will be unaffected by the Startup Plan. The new HA-21I furnaces will be started using empty boat charges until the operators have gained familiarity with the new procedures and logistics of material movement within the processing lines. Phases 1 through 4 will require a minimum of one furnace cycle.

7.2.1.2 Once all furnaces have been operated successfully, one of the HA-21I furnaces will be switched to fissile material operations with empty boat charges in the remaining HA21I furnaces. The next phase will add an additional HA21I furnace with fissile material operations while continuing to operate the other three furnaces with fissile materials, and the fifth furnace operating with an empty boat charge. The final step will be to change the fifth furnace from an empty boat charge to fissile material charge.

7.2.1.3 Fissile material Operations with greater than two furnaces will be commenced after the Director, Plutonium Finishing Plant, has determined that all support equipment and personnel are in place and ready to support the increased production rate. The support services and equipment requirements include:

- Adequate moisture measurement analytical capability to support additional production throughput. 
- Adequate storage of in process material to support the increased production rate.

- Adequate supply of containers to package the processed material.

- Adequate vault storage capacity to store the increased production.

7.2.2 Significant deviations or changes from the Startup Plan shall be reviewed and approved utilizing the same approvals as the original Startup Plan. Minor changes may be authorized by the Manager, PFP Thermal Stabilization.

7.2.3 The objective of this Startup Plan shall be to provide a safe operating sequence for Thermal Stabilization processing that will allow operators to gain experience with the additional operational complexity of increased furnace capacity.

7.2.4 The Startup Plan will be supplemented by a Blend Plan. The Blend Plan will identify the items to be stabilized, and how various stored materials are to be combined for processing.

\subsection{Oversight}

Management oversight will include the normal stabilization organization augmented by the SSW program or other equivalent oversight as directed by the Director, Plutonium Finishing Plant, as scheduled by the Manager, PFP Thermal Stabilization.

\section{$7.4 \quad$ Feed Type Shifts}

Initial processing with the new furnaces will continue the processing of oxide materials. The blend plan, and standard procedures for feed shifts will be used to change feed materials in a coordinated manner. 


\subsection{HOLD POINTS}

Hold Points have been established for this Startup Plan beyond which no additional complex operations can be attempted. The Director, Plutonium Finishing Plant, is responsible for authorizing fissile material operations (Hold Point \#1). The Manager, PFP Thermal Stabilization, is responsible for allowing the continuation of operations (Hold Points \#2 and \#3) as stated in the "Startup Plan of HA-21I Furnaces Approval Checklist", Attachment A. In accomplishing this, he will verify that each step has been completed and signed by the indicated manager. No work activities shall proceed past a Hold Point without the specific approval of the Manager, PFP Thermal Stabilization or Director, Plutonium Finishing Plant, as shown on the Checklist. This will ensure that critical activities are reviewed prior to proceeding from the initial startup approval level to fully integrated five furnace operations. The final Hold Point that allows unrestricted operations will be signed by the Director, Plutonium Finishing Plant.

\subsection{EMERGENCY PLANNING}

Since the five furnace operation is only an extension of existing activities, the normal daily emergency planning and response coverage is adequate, and supplemental emergency plans are not required.

\subsection{DOCUMENTATION}

A list of these preparations is contained in Attachment A, "Startup Plan of HA-21I Furnaces Approval Checklist is to be completed by the Manager, PFP Thermal Stabilization, or his designate, and maintained on file by the Manager, PFP Thermal Stabilization as a QA document in accordance with HNF-PRO-222.

\subsection{REFERENCES}

11.1 "Plutonium Finishing Plant Safety Analysis Report", SD-CP-SAR-021, Rev 1

11.2 "Activity Based Startup Review Plan", 


\section{FIGURE 1 LAYOUT OF HA-21I FURNACES}

\section{Room 230C}

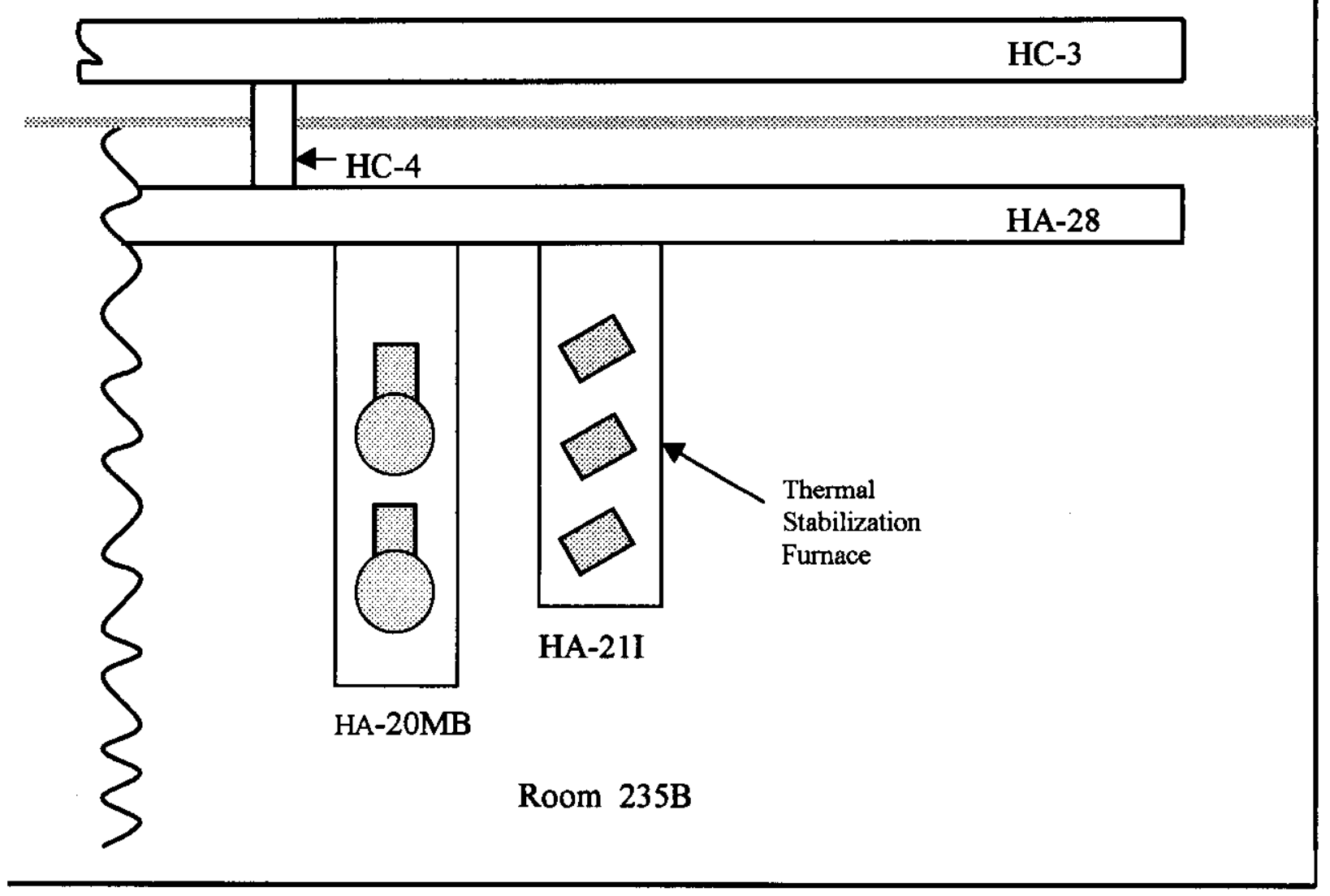

\section{HA-21I Furnace Layout}




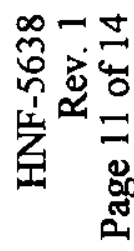

\begin{tabular}{|c|c|c|c|c|c|c|}
\hline 島 & $\mid$ & 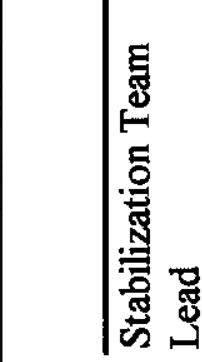 & 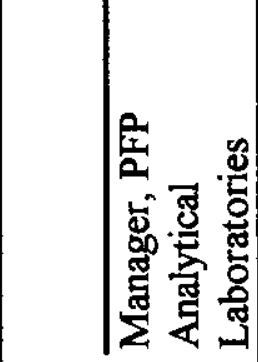 & 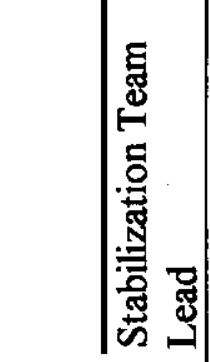 & 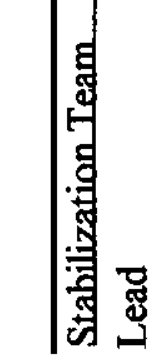 & 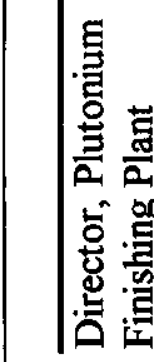 \\
\hline 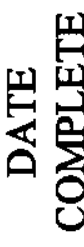 & & & & & & \\
\hline 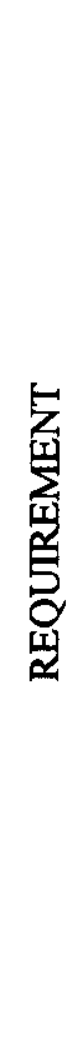 & 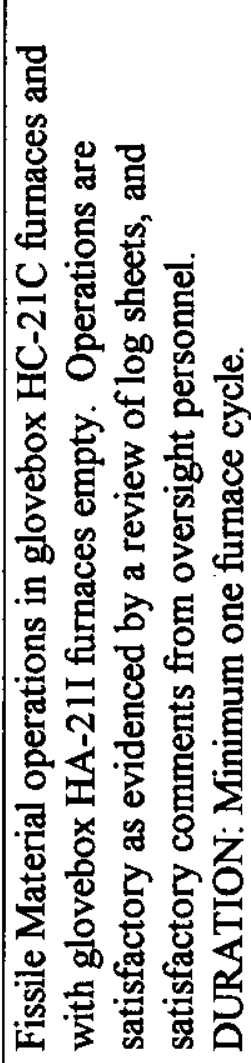 & 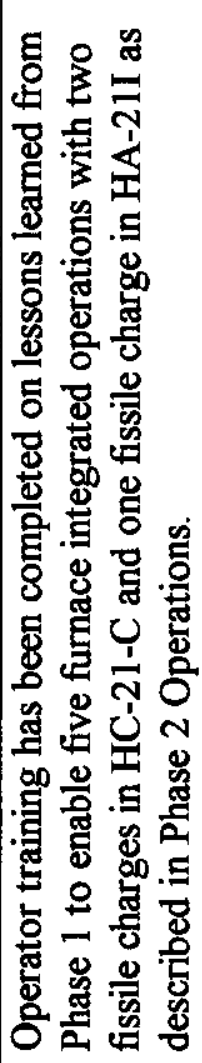 & 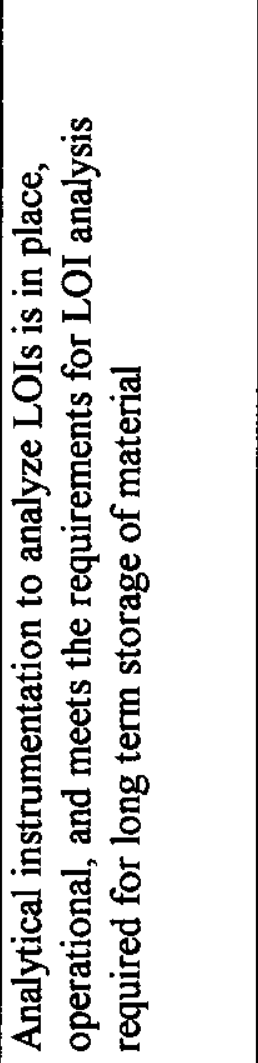 & 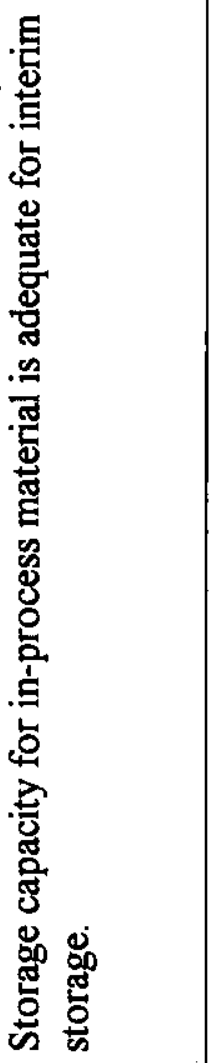 & 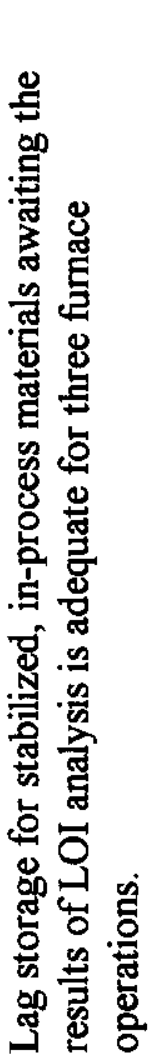 & 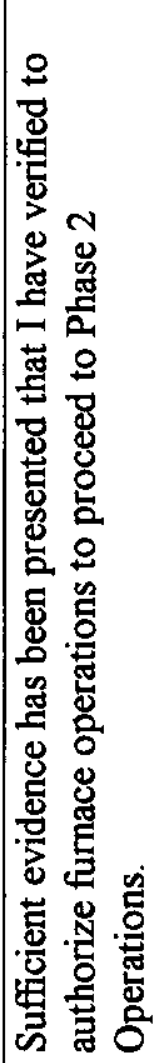 \\
\hline $\begin{array}{l}Z \\
0 \\
0 \\
0 \\
0 \\
0 \\
0 \\
0 \\
0 \\
0\end{array}$ & 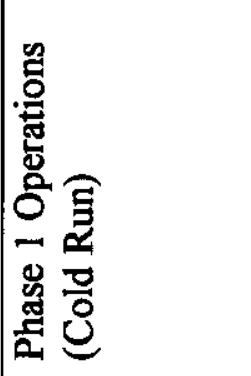 & 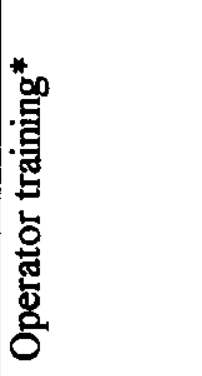 & 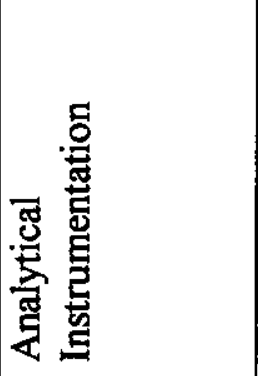 & 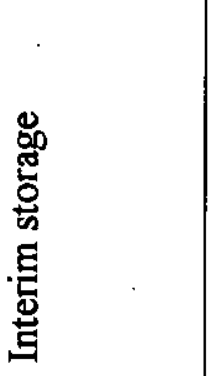 & 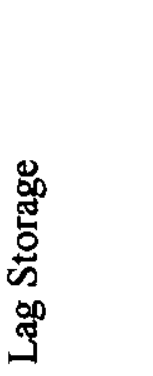 & $\begin{array}{l}7 \\
7 \\
.0 \\
0 \\
0 \\
0 \\
0 \\
0 \\
\end{array}$ \\
\hline$\sum_{\underline{E}}^{*}$ & - & $N$ & $m$ & $\nabla$ & $n$ & 6 \\
\hline
\end{tabular}




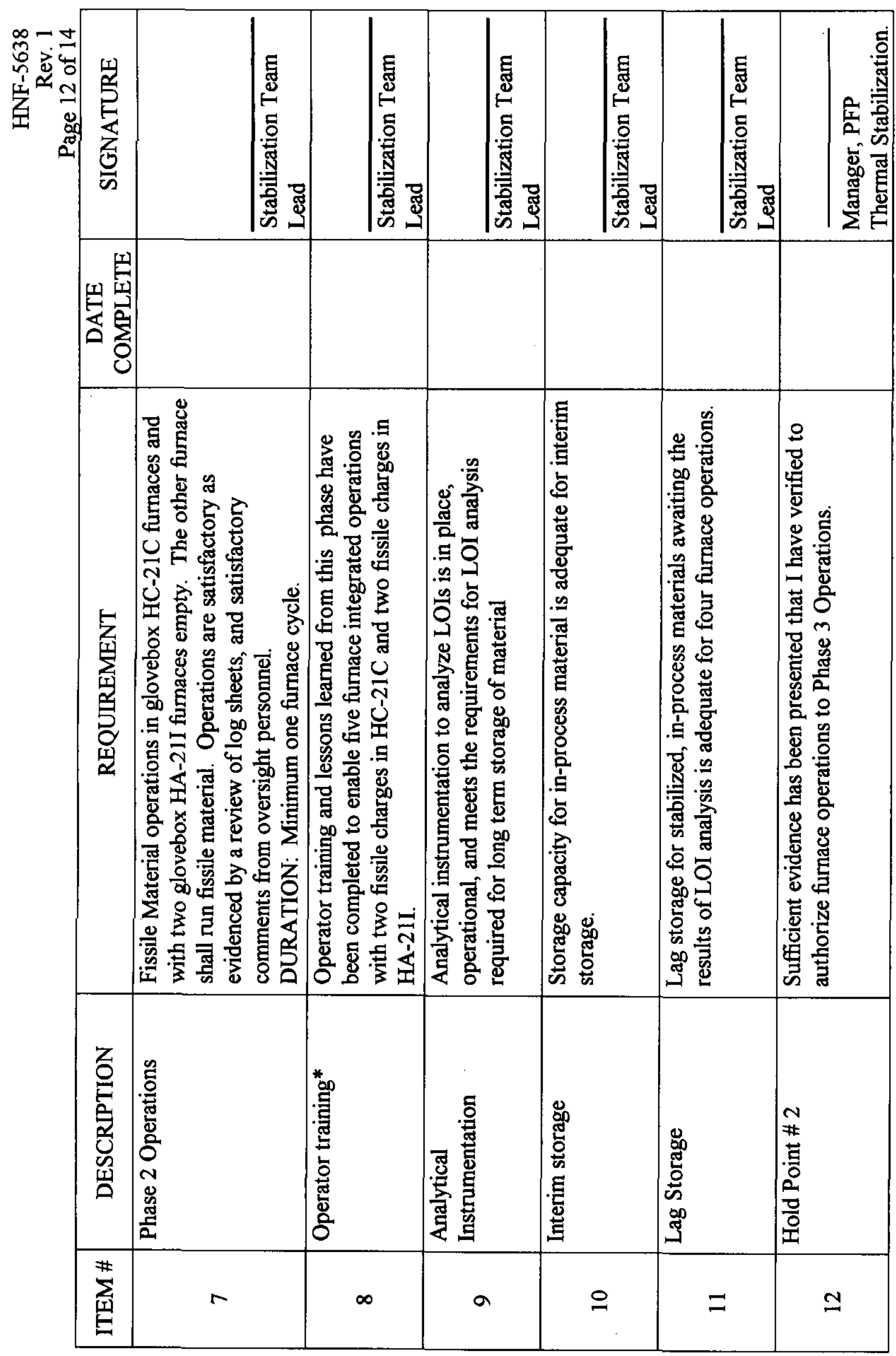




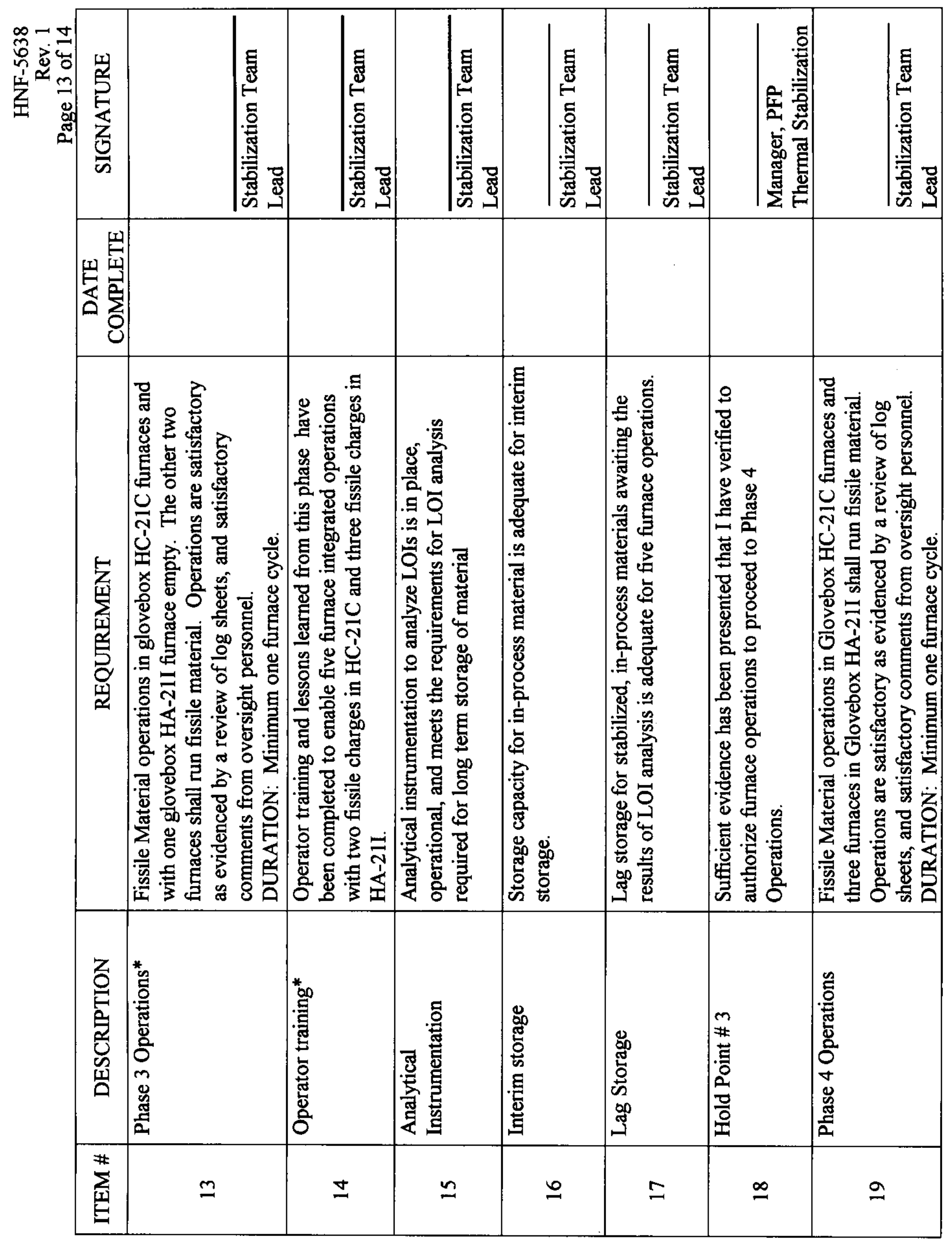




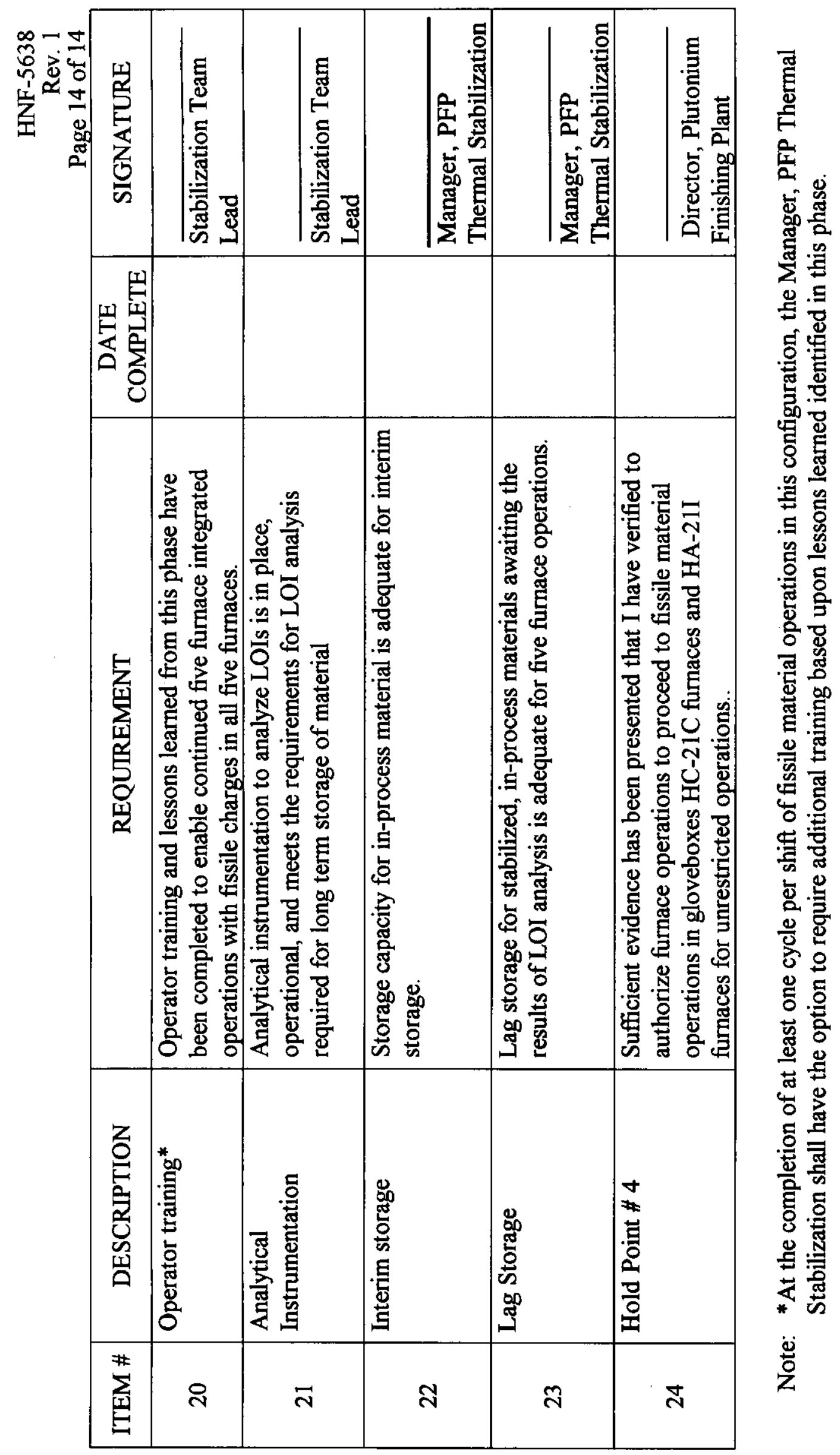

